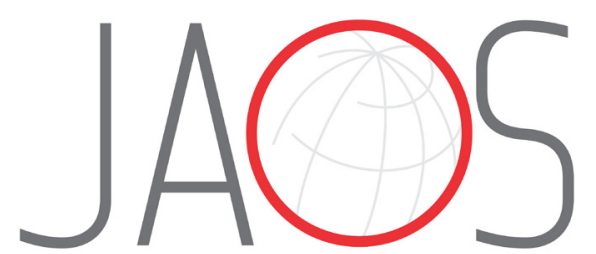
JOURNAL OF APPLIED ORAL SCIENCE

\title{
Two mechanisms of oral malodor inhibition by zinc ions
}

\section{Abstract}

Nao SUZUKI ${ }^{1}$

Yoshio NAKANO ${ }^{2}$

Takeshi WATANABE ${ }^{1}$

Masahiro YONEDA ${ }^{3}$

Takao HIROFUJI ${ }^{3}$

Takashi HANIOKA ${ }^{1}$
Submitted: April 22, 2017 Modification: June 24, 2017

Accepted: July 01, 2017

Corresponding address: Nao Suzuki, DDS, Ph.D. Department of Preventive and Public Health Dentistry, Fukuoka Dental College, 2-15-1 - Tamura Sawara-ku, Fukuoka - 814-0193 - Japan Phone: +81-92-801-0411 - Fax: +81-92-801-4909 e-mail: naojsz@college.fdcnet.ac.jp
Objectives: The aim of this study was to reveal the mechanisms by which zinc ions inhibit oral malodor. Material and Methods: The direct binding of zinc ions to gaseous hydrogen sulfide $\left(\mathrm{H}_{2} \mathrm{~S}\right)$ was assessed in comparison with other metal ions. Nine metal chlorides and six metal acetates were examined. To understand the strength of $\mathrm{H}_{2} \mathrm{~S}$ volatilization inhibition, the minimum concentration needed to inhibit $\mathrm{H}_{2} \mathrm{~S}$ volatilization was determined using serial dilution methods. Subsequently, the inhibitory activities of zinc ions on the growth of six oral bacterial strains related to volatile sulfur compound (VSC) production and three strains not related to VSC production were evaluated. Results: Aqueous solutions of $\mathrm{ZnCl}_{2}, \mathrm{CdCl}_{2}, \mathrm{CuCl}_{2},\left(\mathrm{CH}_{3} \mathrm{COO}\right)_{2} \mathrm{Zn}$, $\left(\mathrm{CH}_{3} \mathrm{COO}\right)_{2} \mathrm{Cd},\left(\mathrm{CH}_{3} \mathrm{COO}\right)_{2} \mathrm{Cu}$, and $\mathrm{CH}_{3} \mathrm{COOAg}$ inhibited $\mathrm{H}_{2} \mathrm{~S}$ volatilization almost entirely. The strengths of $\mathrm{H}_{2} \mathrm{~S}$ volatilization inhibition were in the order $\mathrm{Ag}+>\mathrm{Cd}_{2}+>\mathrm{Cu}_{2}+>\mathrm{Zn}_{2}+$. The effect of zinc ions on the growth of oral bacteria was strain-dependent. Fusobacterium nucleatum ATCC 25586 was the most sensitive, as it was suppressed by medium containing $0.001 \%$ zinc ions. Conclusions: Zinc ions have an inhibitory effect on oral malodor involving the two mechanisms of direct binding with gaseous $\mathrm{H}_{2} \mathrm{~S}$ and suppressing the growth of VSC-producing oral bacteria.

Keywords: Antimicrobial activity. Chemical binding. Hydrogen sulfide. Oral malodor. Zinc ions.
${ }^{1}$ Fukuoka Dental College, Department of Preventive and Public Health Dentistry, Fukuoka, Japan. ${ }^{2}$ Nihon University, School of Dentistry, Department of Chemistry, Tokyo, Japan.

${ }^{3}$ Fukuoka Dental College, Department of General Dentistry, Fukuoka, Japan. 


\section{Introduction}

Oral malodor is primarily the result of microbial metabolism of amino acids from local debris in the oral cavity ${ }^{19}$. The primary compounds of oral malodor are volatile sulfur compounds (VSCs), such as hydrogen sulfide $\left(\mathrm{H}_{2} \mathrm{~S}\right)$, methyl mercaptan $\left(\mathrm{CH}_{3} \mathrm{SH}\right)$, and dimethyl sulfide $\left(\mathrm{CH}_{3} \mathrm{SCH}_{3}\right)^{24}$. Periodontopathic anaerobic bacteria, such as Porphyromonas gingivalis, Treponema denticola, Prevotella intermedia, Fusobacterium nucleatum, and Eubacterium can produce large amounts of $\mathrm{H}_{2} \mathrm{~S}$ and $\mathrm{CH}_{3} \mathrm{SH}$ from cysteine, methionine, or serum proteins ${ }^{16,17}$.

Various anti-malodor agents for oral use have been introduced and have proven to be effective in reducing VSC concentration in the oral cavity. Antimicrobial agents such as chlorhexidine, triclosan, and cetylpyridinium chloride can reduce oral malodor by reducing the number of microorganisms present in the mouth ${ }^{3}$. Chlorine dioxide has also been shown to reduce oral malodor by chemically neutralizing VSCs $^{12}$. Natural ingredients, such as hinokitiol, green tea powder, and Eucalyptus extract, also reduce oral malodor through various antibacterial mechanisms $7,11,22$.

Zinc ions are often found in commercial antimalodor mouthwashes in combination with other active ingredients. A combination of zinc ions and chlorhexidine or cetylpyridinium chloride was reported to inhibit VSC production synergistically ${ }^{29}$. We considered two mechanisms of oral malodor inhibition by zinc ions. The first is that zinc ions have a strong affinity for the thiol groups present in $\mathrm{VSCs}^{28}$. Zinc ions exhibit immediate inhibitory effects on VSC production compared to chlorhexidine ${ }^{30}$, by effectively and directly reducing the activities of VSCs. The second is that zinc ions have an antibacterial effect. Zinc ions can inhibit catabolism by $F$. nucleatum and $P$. intermedia ${ }^{20}$, and acid production by Streptococcus sobrinus and Streptococcus salivarius ${ }^{6}$. Although these characteristics suggest that zinc ions might be effective oral anti-malodor agents, the majority of studies conducted to date have been based on the results of clinical use in combination with other agents. Therefore, the two mechanisms of action, chemical binding and an antimicrobial property, have not been individually assessed. Furthermore, previous in vitro studies examined the inhibitory effects of zinc ions only on the functions of selected targets, and thus the antimicrobial effects of zinc ions on microorganisms related to oral malodor remain unclear. In this study, the direct effects of zinc ions on $\mathrm{H}_{2} \mathrm{~S}$ were assessed in comparison with other metal ions. In addition, the inhibitory effects of zinc ions on the growth of microorganisms related to VSC production and those unrelated to VSC production were evaluated.

\section{Materials and methods}

\section{Direct inhibitory effects of metal ions on hydrogen sulfide}

Nine metal chlorides, namely, $\mathrm{MgCl}_{2}, \mathrm{Al}_{2} \mathrm{Cl}_{3}, \mathrm{CaCl}_{2}$, $\mathrm{MnCl}_{2}, \mathrm{FeCl}_{2}, \mathrm{CuCl}_{2}, \mathrm{ZnCl}_{2}, \mathrm{SrCl}_{2}$, and $\mathrm{CdCl}_{2}$, and six metal acetates, namely, $\left(\mathrm{CH}_{3} \mathrm{COO}\right)_{2} \mathrm{Ca},\left(\mathrm{CH}_{3} \mathrm{COO}\right)_{2} \mathrm{Fe}$, $\left(\mathrm{CH}_{3} \mathrm{COO}\right)_{2} \mathrm{Cu}$, $\left(\mathrm{CH}_{3} \mathrm{COO}\right)_{2} \mathrm{Zn}, \mathrm{CH}_{3} \mathrm{COOAg}$, and $\left(\mathrm{CH}_{3} \mathrm{COO}\right)_{2} \mathrm{Cd}$, were examined in this study. These chemical compounds, except for $\left(\mathrm{CH}_{3} \mathrm{COO}\right)_{2} \mathrm{Cu}$ and $\mathrm{CH}_{3} \mathrm{COOAg}$, were prepared as $1 \mathrm{M}$ aqueous solutions. The aqueous solutions of $\left(\mathrm{CH}_{3} \mathrm{COO}\right)_{2} \mathrm{Cu}$ and $\mathrm{CH}_{3} \mathrm{COOAg}$ were prepared at concentrations of $0.25 \mathrm{M}$ and 0.0625 $M$, respectively. Gaseous $\mathrm{H}_{2} \mathrm{~S}$ was prepared from a dilute aqueous solution of $\mathrm{NaHS}_{\mathrm{nH}} \mathrm{S}$. Two milliliters of aqueous solution containing $10^{-5} \% \mathrm{NaHS}_{2} \mathrm{nH}_{2} \mathrm{~S}$ and the appropriate chemical compound was added to individual $15 \mathrm{~mL}$ tubes, which were sealed and incubated at room temperature for $5 \mathrm{~min}$. Then, 1 $\mathrm{mL}$ of the gas phase was collected and measured by gas chromatography (model GC2014; Shimadzu Works, Kyoto, Japan). To determine which chemical compounds inhibited $\mathrm{H}_{2} \mathrm{~S}$ volatilization more strongly, the minimum concentrations of $\mathrm{H}_{2} \mathrm{~S}$ volatilization inhibition were determined using serial dilution methods. All test reagents were purchased from WAKO Pure Chemical Industries, Ltd. (Kyoto, Japan). The experiments were repeated at least three times.

\section{Inhibitory effects of zinc ions on the growth of oral bacteria}

The bacterial strains used in the study are $P$. gingivalis FDC $381, P$. gingivalis W83, $P$. gingivalis ATCC 33277, F. nucleatum ATCC 25586, P. intermedia ATCC 25611, Streptococcus mutans JCM 5705, S. sobrinus JCM 5176, S. salivarius GTC 0215, and Streptococcus anginosus FW73. The S. mutans, S. sobrinus, S. salivarius, and S. anginosus strains were cultivated in $\mathrm{BD}$ Bacto ${ }^{\mathrm{TM}}$ brain heart infusion (BHI) medium (Becton, Dickinson and Company, Franklin Lakes, NJ, USA), while $P$. gingivalis, F. nucleatum, 
and $P$. intermedia were cultivated in $\mathrm{BHI}$ medium with hemin $(5 \mu \mathrm{g} / \mathrm{mL})$ and vitamin $\mathrm{K}(1 \mu \mathrm{g} / \mathrm{mL})$.

Bacterial cultures were incubated at $37^{\circ} \mathrm{C}$ anaerobically until full growth, then suspended in fresh $\mathrm{BHI}$ medium or fresh $\mathrm{BHI}$ medium with hemin and vitamin $\mathrm{K}$ to an optical density at $600 \mathrm{~nm}\left(\mathrm{OD}_{600}\right)$ of 0.3 . To evaluate the effect of zinc ions on the growth of bacteria, $100 \mu \mathrm{L}$ of the inoculated medium was cultivated anaerobically in a final volume of 200 $\mu \mathrm{L}$ of $\mathrm{ZnCl}_{2}$-containing $\mathrm{BHI}$ medium or $\mathrm{BHI}$ medium with hemin and vitamin $\mathrm{K}$. The final concentrations of $\mathrm{ZnCl}_{2}$ in the culture solutions were $0.1 \%(0.007 \mathrm{M})$, $0.01 \%(0.0007 \mathrm{M}), 0.001 \%(0.00007 \mathrm{M})$, and $0 \%$ (control, 0 M). Cultivation was performed in a 96-well (flat-bottomed) microtiter plate (Nunc A/S, Roskilde, Denmark). After suspending the bacterial cells by pipetting, the optical density at $600 \mathrm{~nm}\left(\mathrm{OD}_{600}\right)$ was measured at $0 \mathrm{~h}, 12 \mathrm{~h}$, and $24 \mathrm{~h}$ for Gram-positive bacteria and at $0 \mathrm{~h}, 12 \mathrm{~h}, 24 \mathrm{~h}$, and $48 \mathrm{~h}$ for Gramnegative bacteria. The experiments were repeated at least three times.

\section{Statistical analysis}

The Mann-Whitney $U$-test was used to evaluate the direct inhibitory effects of metal ions on gaseous $\mathrm{H}_{2} \mathrm{~S}$ compared with $10^{-5} \% \mathrm{NaHS} . \mathrm{nH}_{2} \mathrm{~S}$ solution, and the inhibitory effects of zinc ions on the growth of oral bacteria compared with that in the $0 \% \mathrm{ZnCl}_{2}$ medium. Differences were considered to be significant when $\mathrm{P}<0.05$. Statistical evaluations were carried out using the R software package, ver. 3.4 .0 (http://www.Rproject.org).

(A)

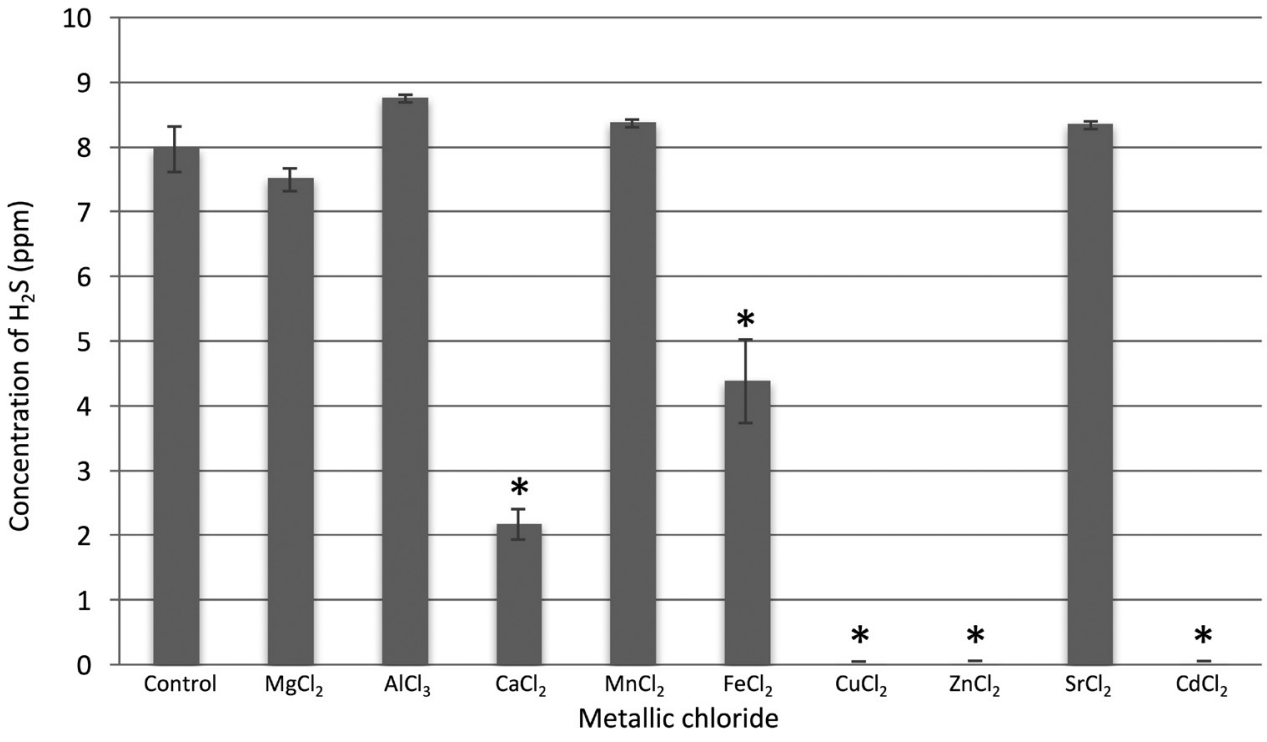

(B)

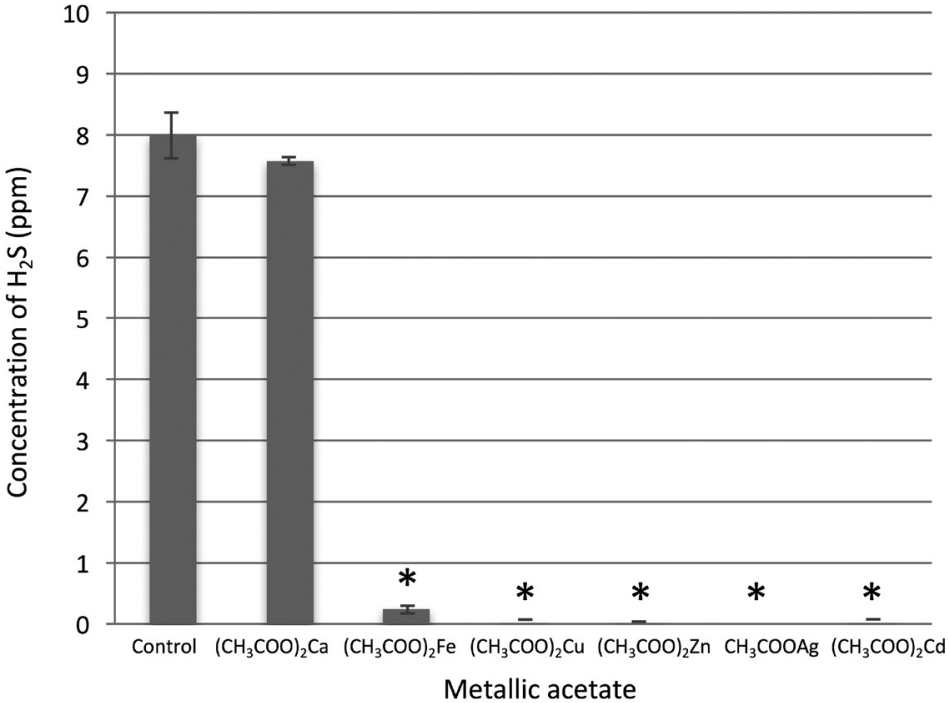

${ }^{*} \mathrm{P}<0.05$ compared with the $10-5 \% \mathrm{NaHS}_{\mathrm{nH}} \mathrm{S}$ solution (Mann-Whitney U-test).

Figure 1- The direct inhibitory effects of aqueous solutions of metal chlorides (A) and metal acetates (B) on gaseous $\mathrm{H}_{2} \mathrm{~S}$ 


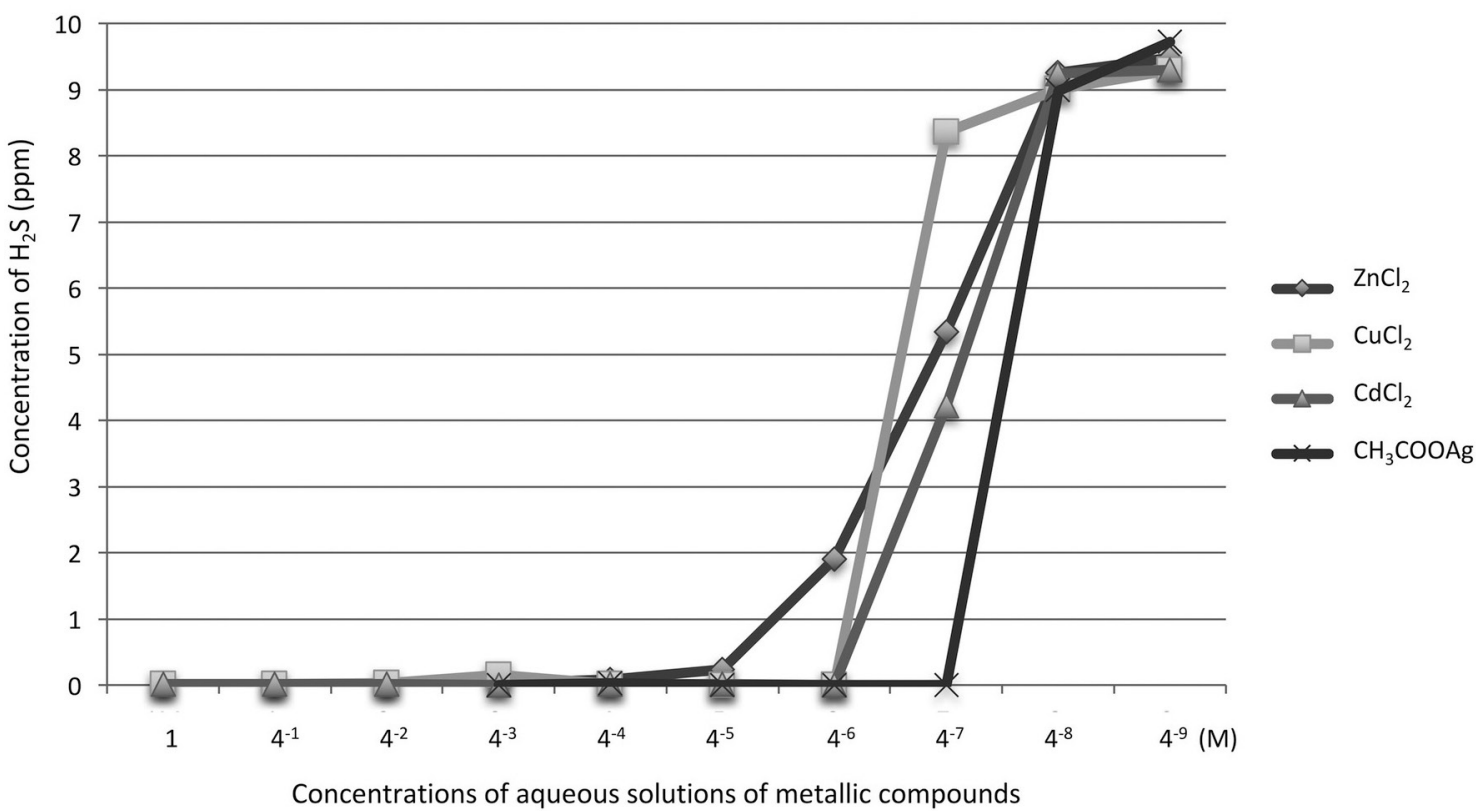

Figure 2- Determination of the minimum concentrations for inhibition of $\mathrm{H}_{2} \mathrm{~S}$ volatilization using serially diluted aqueous solutions of $\mathrm{ZnCl}$, $\mathrm{CuCl}_{2}, \mathrm{CdCl}_{2}$, and $\mathrm{CH}_{3} \mathrm{COOAg}$. The strength of $\mathrm{H}_{2} \mathrm{~S}$ volatilization inhibition was in the following order: $\mathrm{Ag}+>\mathrm{Cu}_{2}+>\mathrm{Cd}_{2}+>\mathrm{Zn}_{2}+$

\section{Results}

\section{Direct inhibitory effects of metal ions on hydrogen sulfide}

The inhibitory effects of metal chlorides on gaseous $\mathrm{H}_{2} \mathrm{~S}$ are shown in Figure $1 \mathrm{~A}$. Aqueous solutions of $\mathrm{ZnCl}_{2}, \mathrm{CuCl}_{2}$, and $\mathrm{CdCl}_{2}$ almost entirely inhibited $\mathrm{H}_{2} \mathrm{~S}$ volatilization. The $\mathrm{CaCl}_{2}$ and $\mathrm{FeCl}_{2}$ solutions moderately inhibited $\mathrm{H}_{2} \mathrm{~S}$ volatilization, at $72.7 \%$ and $45.0 \%$, respectively. There was a statistically significant difference between each of these five metal chlorides and the control $(\mathrm{P}<0.05)$. Aqueous $\mathrm{MgCl}_{2}, \mathrm{AlCl}_{3}, \mathrm{MnCl}_{2}$, and $\mathrm{SrCl}_{2}$ solutions did not inhibit $\mathrm{H}_{2} \mathrm{~S}$ volatilization. For metal chlorides that directly inhibited gaseous $\mathrm{H}_{2} \mathrm{~S}$, as well as hydrophobic silver chloride, we assessed the inhibitory effects of the metal acetates of the same ions on gaseous $\mathrm{H}_{2} \mathrm{~S}$ (Figure 1B). The $\left(\mathrm{CH}_{3} \mathrm{COO}\right)_{2} \mathrm{Zn}$ and $\mathrm{CH}_{3} \mathrm{COOAg}$ solutions inhibited $\mathrm{H}_{2} \mathrm{~S}$ volatilization entirely $(100 \%$ and $100 \%)(\mathrm{P}<0.05)$, while $\left(\mathrm{CH}_{3} \mathrm{COO}\right)_{2} \mathrm{Fe}$, $\left(\mathrm{CH}_{3} \mathrm{COO}\right)_{2} \mathrm{Cu}$, and $\left(\mathrm{CH}_{3} \mathrm{COO}\right)_{2} \mathrm{Cd}$ inhibited it almost entirely $(97.0 \%, 99.8 \%$, and $99.9 \%)(\mathrm{P}<0.05)$. Overall, four ions, zinc, copper, cadmium, and silver, were considered to have excellent inhibitory effects on $\mathrm{H}_{2} \mathrm{~S}$ volatilization. Serially diluted aqueous solutions of $\mathrm{ZnCl}_{2}, \mathrm{CuCl}_{2}, \mathrm{CdCl}_{2}$, and $\mathrm{CH}_{3} \mathrm{COOAg}$ were assessed to determine the minimum concentration that inhibits $\mathrm{H}_{2} \mathrm{~S}$ volatilization (Figure 2 ). The $\mathrm{CH}_{3} \mathrm{COOAg}$ solution exhibited the strongest effect, as it inhibited $\mathrm{H}_{2} \mathrm{~S}$ volatilization entirely at $4^{-7} \mathrm{M}$. Comparing the strength of $\mathrm{H}_{2} \mathrm{~S}$ volatilization inhibition among metals, the order was as follows: $\mathrm{Ag}^{+}>\mathrm{Cd}^{2+}>\mathrm{Cu}^{2+}>\mathrm{Zn}^{2+}$.

\section{Inhibitory effects of zinc ions on the growth of oral bacteria}

Among the tested oral bacteria, F. nucleatum ATCC 25586 was the most sensitive, as it was suppressed by $0.001 \%$ zinc ions in the medium (Figure 3 ). The growth of S. sobrinus JCM 5716, S. salivarius GTC 0215, $P$. gingivalis ATCC $33277, P$. gingivalis W83, and $P$. intermedia ATCC 25611 was suppressed in medium with $0.01 \%$ zinc ions. For $P$. intermedia ATCC 25611, medium with $0.001 \%$ zinc ions suppressed bacterial growth for the first $24 \mathrm{~h}$. The growth of S. mutans JCM 5705 was suppressed in medium with $0.1 \%$ zinc ions, but not in medium with $0.01 \%$ zinc ions. Although the growth of $S$. anginosus FW73 was suppressed in media with $0.1 \%$ and $0.01 \%$ zinc ions, the inhibitory effect of $0.01 \%$ zinc ions was not complete. $P$. gingivalis FDC 381 increased in the first $12 \mathrm{~h}$ in medium with $0.1 \%$ zinc ions as well as $0.01 \%$ zinc ions, but exhibited no further growth at $24 \mathrm{~h}$ and $48 \mathrm{~h}$.

\section{Discussion}

Among the nine metal ions examined in this study, calcium, iron, zinc, cadmium, copper, and silver had direct inhibitory effects on $\mathrm{H}_{2} \mathrm{~S}$ volatilization. These metals have been widely used in dental materials, 

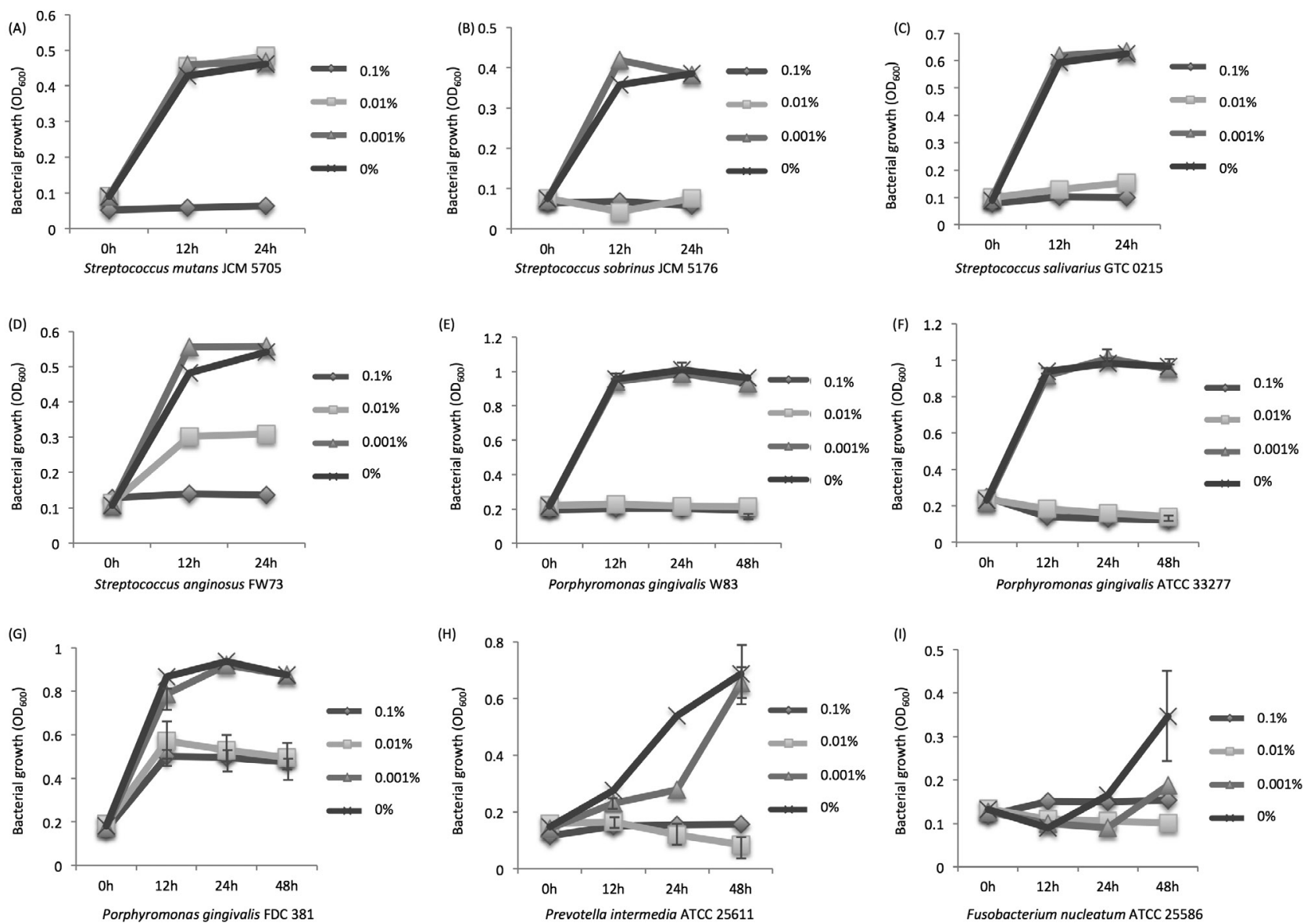

Figure 3- Inhibitory effects of zinc ions on the growth of oral bacteria (mean \pm SD). Streptococcus mutans JCM5705 (A), Streptococcus sobrinus (B), Streptococcus salivarius GTC0215 (C), Streptococcus anginosus FW73 (D), Porphyromonas gingivalis W83 (E), ATCC 33277 (F), FDC $381(\mathrm{G})$, Prevotella intermedia ATCC $25611(\mathrm{H})$, and Fusobacterium nucleatum ATCC 25586 (I)

except for cadmium, which can have harmful effects on health. Iron, zinc, copper, and silver are not only used alone in tooth restorations but are also mixed into alloys due to their antimicrobial nature ${ }^{1,8,10,23}$. Calcium and silver are also used as antibacterial fillings for intractably infected root canals ${ }^{4}$. Iron ions have an inhibitory effect on glycosyltransferase enzymes of S. mutans, and a previous study reported that ironcontaining sucrose reduced the amount of mutans streptococci in biofilm compared with sucrose ${ }^{28}$. For inhibition of odor in the oral cavity, zinc has been extensively studied and developed, whereas other metal ions have not been evaluated for this purpose. However, these metal ions exhibited direct inhibitory effects on $\mathrm{H}_{2} \mathrm{~S}$ volatilization in this study, in addition to their previously reported antimicrobial effects. In particular, the inhibitory effects of copper and silver on $\mathrm{H}_{2} \mathrm{~S}$ volatilization were excellent compared with that of zinc. The effects of these metal ions released from dental materials might thus contribute to reduce oral malodor due to antimicrobial effects and inhibition of $\mathrm{H}_{2} \mathrm{~S}$ volatilization. Liu, et al. ${ }^{10}$ (2016) reported that $\mathrm{Ti}-\mathrm{Cu}$ alloy implants released about $0.014 \mu \mathrm{g} /$ day of
$\mathrm{Cu}^{2+}$ ions, which is considerably lower than the minimal inhibitory concentration of $\mathrm{Cu}^{2+}$ for Staphylococcus aureus and Escherichia coli. The authors also explored the antibacterial activities of Ti-Cu alloy against $P$. gingivalis and S. mutans, and postulated that $\mathrm{Ti}-\mathrm{Cu}$ alloys might exhibit antimicrobial activity markedly even if low levels of $\mathrm{Cu}^{2+}$ ions are released.

The $\mathrm{ZnCl}_{2}$ solution inhibited $\mathrm{H}_{2} \mathrm{~S}$ volatilization entirely at $4^{-4} \mathrm{M}(0.053 \%)$ in the current in vitro experiment. Young, et al. ${ }^{28}$ (2001) reported approximately $80 \%$ reduction of oral hydrogen sulfide after $1 \mathrm{~h}$ in a clinical trial of rinsing with $0.1 \% \mathrm{ZnCl}_{2}$ solution. In other previous studies, zinc ions were usually combined with other antimicrobial agents, such as chlorhexidine, cetylpyridinium chloride, or triclosan ${ }^{14,18,29}$, and the concentrations of zinc compounds were in the range of $0.14 \%$ to $0.4 \%$, which were effective for direct inhibition of $\mathrm{H}_{2} \mathrm{~S}$ volatilization in an in vitro study. The recommended intake and tolerable intake of zinc established by the Food and Agriculture Organization of the United Nations and the World Health Organization (FAO/WHO) are 14-20 mg/day and 0.3-1 mg/kg body weight/day, respectively ${ }^{26}$, and therefore effective and 
safe concentrations of zinc ions can be incorporated into mouthwash. On the other hand, Japanese law requires the concentrations of some synthetic antimicrobial agents combined with dentifrice or mouthwash to be lower than their effective concentrations due to occurrences of anaphylactic shock ${ }^{15}$. For example, chlorhexidine and cetylpyridinium chloride are limited to $0.05 \%$ and $0.01 \%$, respectively, although foreign studies examining the effectiveness of these compounds on oral malodor have been performed using $0.1 \%-0.2 \%$ chlorhexidine and $0.05 \%-0.07 \%$ cetylpyridinium chloride ${ }^{2,25}$. Interestingly, it has been reported that mouthwash containing $0.3 \%$ zinc acetate and $0.025 \%$ chlorhexidine showed a synergistic antiVSC effect ${ }^{30}$. By combining multiple components, the concentration of each can be kept low. Furthermore, this synergistic effect indicates different mechanisms of VSC inhibition by each component.

The effect of zinc ions on the growth of oral bacteria was strain-dependent. $F$. nucleatum, $P$. intermedia, and $P$. gingivalis have been recognized as VSC-producing organisms that are important to oral malodor ${ }^{21}$. F. nucleatum and $P$. intermedia were especially sensitive to zinc ions compared with other bacteria assessed in this study. The growth of $F$. nucleatum ATCC 25586 and P. intermedia ATCC 25611 was suppressed entirely and for $24 \mathrm{~h}$, respectively, with $0.001 \% \mathrm{ZnCl}_{2}$. The growth of $P$. gingivalis $\mathrm{W} 83$ and ATCC 33277 was entirely suppressed by $0.01 \% \mathrm{ZnCl}_{2}$, whereas strain FDC 381 increased for the first $12 \mathrm{~h}$ at both $0.01 \%$ and $0.1 \% \mathrm{ZnCl}_{2}$ and then stopped growing. Gram-negative strict anaerobes have been identified as the main organisms capable of producing $\mathrm{H}_{2} \mathrm{~S}$, but $S$. anginosus, which is a Gram-positive microaerophilic anaerobe, has a greater capacity to produce $\mathrm{H}_{2} \mathrm{~S}$ from L-cysteine than other oral streptococci ${ }^{27}$. The growth of S. anginosus FW73 increased for the first $12 \mathrm{~h}$ with $0.01 \% \mathrm{ZnCl}_{2}$ and then stopped. The growth of S. mutans JCM 5705, S. sobrinus JCM 5176, and S. salivarius GTC 0215, considered unimportant for $\mathrm{H}_{2} \mathrm{~S}$ production, was suppressed by $0.1 \% \mathrm{ZnCl}_{2}, 0.01 \%$ $\mathrm{ZnCl}_{2}$, and $0.01 \% \mathrm{ZnCl}_{2}$, respectively. In a previous study on the effects of silver ions on the growth of $S$. aureus and $E$. coli ${ }^{9}$, sensitivity may have been affected by the thickness of the peptidoglycan layer, which may inhibit ion passage through the Gram-positive bacterial cell wall. Differences in the zinc sensitivities of $P$. gingivalis strains should be investigated in the future.

This study determined that zinc ions inhibit oral malodor by two mechanisms, direct inhibition of $\mathrm{H}_{2} \mathrm{~S}$ volatilization and antimicrobial activity. Both mechanisms may be caused by the strong affinity for the thiol groups characteristic of metal ions, including zinc ions. The direct reaction experiment between gaseous $\mathrm{H}_{2} \mathrm{~S}$ and metal ions verified the first mechanism. Concerning the second mechanism, it has been reported that sulfur-containing amino acids such as cysteine and glutathione neutralized the activity of silver ions on bacteria ${ }^{5,13}$. This finding shows that metal ions react with sulfur-containing intracellular and extracellular amino acids, causing functional failure of proteins and resulting in damage to bacterial cells. In addition, functional failure of proteins may lead to the production of reactive oxygen species. In fact, the antimicrobial action of silver ions increased in the presence of oxygen ${ }^{5}$, which suggests that the generation of reactive oxygen species is related to the antimicrobial activity of metal ions.

There are several limitations to this study. First, the main VSC compounds related to odor in the oral cavity are $\mathrm{H}_{2} \mathrm{~S}$ and $\mathrm{CH}_{3} \mathrm{SH}$. Only the effect of zinc ions on $\mathrm{H}_{2} \mathrm{~S}$ production was evaluated, and the effect on $\mathrm{CH}_{3} \mathrm{SH}$ should also be assessed. Second, no sustainability assessment of the inhibitory effect of zinc ions on $\mathrm{H}_{2} \mathrm{~S}$ volatilization was performed in this study. A previous clinical trial reported that the inhibitory effect of rinsing with $0.1 \% \mathrm{ZnCl}_{2}$ on $\mathrm{H}_{2} \mathrm{~S}$ continued for only 1 hour, less than those of $\mathrm{SnF}_{2}$ and $\mathrm{CuCl}_{2}{ }^{28}$. The longitudinal evaluation of the binding reaction between zinc ions and $\mathrm{H}_{2} \mathrm{~S}$ should be performed in vitro. Finally, the antimicrobial mechanism of zinc ions has been compared to the characteristics of silver ions, which have been studied well. The reason why the effect of zinc ions is weaker than those of silver and copper ions remains unclear. Further investigations into the chemical reactivity between zinc ions and thiol groups as well as the specific active sites of antimicrobial activity of zinc ions are necessary.

In conclusion, zinc ions, which exhibit an inhibitory effect on VSCs and are incorporated into products for oral malodor prevention, employ the two mechanisms of direct binding with gaseous $\mathrm{H}_{2} \mathrm{~S}$ and antimicrobial activity. In particular, the growth of bacteria related to VSC production was inhibited at a lower concentration of $\mathrm{ZnCl}_{2}$ compared with bacteria not related to VSC production. 


\section{Acknowledgements}

This study was supported in part by Grants-in-Aid for Scientific Research (nos. 26463175, 15K14423, and 16K07205) from the Ministry of Education, Culture, Sports, Science and Technology of Japan, from the Sato Fund (2015-2016) of Nihon University School of Dentistry. The authors declare that they have no competing interests. We thank Asoh M and Sakata R, who are dental students at Fukuoka Dental College, for contributing to the experiments in the study.

\section{References}

1- Abdulkareem EH, Memarzadeh K, Allaker RP, Huang J, Pratten J, Spratt D. Anti-biofilm activity of zinc oxide and hydroxyapatite nanoparticles as dental implant coating materials. J Dent. 2015;43(12):1462-9. 2- Berchier CE, Slot DE, Van der Weijden GA. The efficacy of $0.12 \%$ chlorhexidine mouthrinse compared with $0.2 \%$ on plaque accumulation and periodontal parameters: a systematic review. J Clin Periodontol. 2010;37(9):829-39.

3- Cortelli JR, Barbosa MD, Westphal MA. Halitosis: a review of associated factors and therapeutic approach. Braz Oral Res. 2008;22 Suppl 1:44-54.

4- Fan W, Wu Y, Ma T, Li Y, Fan B. Substantivity of Ag-Ca-Si mesoporous nanoparticles on dentin and its ability to inhibit Enterococcus faecalis. J Mater Sci Mater Med. 2016;27(1):16.

5- Furr JR, Russell AD, Turner TD, Andrews A. Antibacterial activity of Actisorb Plus, Actisorb and silver nitrate. J Hosp Infect. 1994;27(3):201-8.

6- He G, Pearce EI, Sissons $\mathrm{CH}$. Inhibitory effect of $\mathrm{ZnCl} 2$ on glycolysis in human oral microbes. Arch Oral Biol. 2002;47(2):117-29.

7- Iha K, Suzuki N, Yoneda M, Takeshita T, Hirofuji T. Effect of mouth cleaning with hinokitiol-containing gel on oral malodor: a randomized, open-label pilot study. Oral Surg Oral Med Oral Pathol Oral Radiol. 2013;116(4):433-9.

8- Ionescu AC, Brambilla E, Travan A, Marsich E, Donati I, Gobbi P, et al. Silver-polysaccharide antimicrobial nanocomposite coating for methacrylic surfaces reduces Streptococcus mutans biofilm formation in vitro. J Dent. 2015;43(12);1483-90.

9- Jung WK, Koo HC, Kim KW, Shin S, Kim SH, Park YH. Antibacterial activity and mechanism of action of the silver ion in Staphylococcus aureus and Escherichia coli. Appl Environ Microbiol. 2008;74(7):21718.

10- Liu R, Memarzadeh K, Chang B, Zhang Y, Ma Z, Allaker RP, et al. Antibacterial effect of copper-bearing titanium alloy ( $\mathrm{Ti}-\mathrm{Cu}$ ) against Streptococcus mutans and Porphyromonas gingivalis. Sci Rep. 2016;6:29985.

11- Lodhia P, Yaegaki K, Khakbaznejad A, Imai T, Sato T, Tanaka T, et al. Effect of green tea on volatile sulfur compounds in mouth air. J Nut Sci Vitaminol (Tokyo). 2008;54(1):89-94.

12- Lynch E, Sheerin A, Claxson AW, Atherton MD, Rhodes CJ, Silwood $\mathrm{CJ}$, et al. Multicomponent spectroscopic investigations of salivary antioxidant consumption by an oral rinse preparation containing the stable free radical species chlorine dioxide $(\mathrm{ClO} 2)$. Free Radic Res. 1997;26(3):209-34.
13- Matsumura Y, Yoshikata K, Kunisaki S, Tsuchido T. Mode of bacterial action of silver zeolite and its comparison with that of silver nitrate. App Environ Microbiol. 2003;69(7):4278-81.

14- Mendes L, Coimbra J, Pereira AL, Resende M, Pinto, MG. Comparative effect of a new mouthrinse containing chlorhexidine, triclosan and zinc on volatile sulphur compounds: a randomized, crossover, double-blind study. Int J Dent Hyg. 2016;14(3):202-8. 15- Okano M, Nomura M, Hata S, Okada N, Sato K, Kitano Y, et al. Anaphylactic symptoms due to chlorhexidine gluconate. Arch Dermatol. 1989;125(1):50-2.

16- Persson S, Claesson R, Carlsson J. The capacity of subgingival microbiotas to produce volatile sulfur compounds in human serum. Oral Microbiol Immunol. 1989;4(3):169-72.

17- Persson S, Edlund MB, Claesson R, Carlsson J. The formation of hydrogen sulfide and methyl mercaptan by oral bacteria. Oral Microbiol Immunol. 1990;5(4):195-201.

18- Schaeken MJ, Van der Hoeven JS, Saxton CA, Cummins D. The effect of mouthrinses containing zinc and triclosan on plaque accumulation, development of gingivitis and formation of calculus in a 28-week clinical test. J Clin Periodontol. 1996;23(5)465-70.

19- Scully C, Porter S, Greenman J. What to do about halitosis. BMJ. 1994;308(6923):217-8.

20- Sheng J, Nguyen PT, Marquis RE. Multi-target antimicrobial actions of zinc against oral anaerobes. Arch Oral Biol. 2005;50(8)747-57.

21- Takeshita T, Suzuki N, Nakano Y, Yasui M, Yoneda M, Shimazaki Y, et al. Discrimination of the oral microbiota associated with high hydrogen sulfide and methyl mercaptan production. Sci Rep. 2012;2:215.

22- Tanaka M, Toe M, Nagata H, Ojima M, Kuboniwa M, Shimizu K, et al. Effect of eucalyptus-extract chewing gum on oral malodor: a double-masked, randomized trial. J Periodontol. 2010;81(11):1564-71. 23- Thukkaram M, Sitaram S, Kannaiyan SK, Subbiahdoss G. Antibacterial efficacy of iron-oxide nanoparticles against biofilms on different biomaterial surfaces. Int J Biomater. 2014;2014:716080.

24- Tonzetich J. Direct gas chromatographic analysis of sulphur compounds in mouth air in man. Arch Oral Biol. 1971;16(6)587-97. 25- Witt J, Bsoul S, He T, Gibb R, Dunavent J, Hamilton A. The effect of toothbrushing regimens on the plaque inhibitory properties of an experimental cetylpyridinium chloride mouthrinse. J Clin Periodontol. 2006;33(10)737-42.

26- World Health Organization - WHO. Evaluation of certain food additives and contaminants: twenty-sixth report of the joint FAO/WHO expert committee on Food Additives. Geneva: The Organization; 1982. Technical Report Series 683.

27- Yoshida $Y$, Nakano $Y$, Amano A, Yoshimura M, Fukamachi $\mathrm{H}$, Oho $\mathrm{T}$, et al. Icd from Streptococcus anginosus encodes a C-S lyase with alpha, beta-elimination activity that degrades L-cysteine. Microbiology. 2002;148(Pt 12):3961-70.

28- Young A, Jonski G, Rölla G, Wåler SM. Effects of metal salts on the oral production of volatile sulfur-containing compounds (VSC). J Clin Periodontol. 2001;28(8):776-81.

29- Young A, Jonski G, Rölla G. Combined effect of zinc ions and cationic anitibacterial agents on intraoral volatile sulphur compounds (VSC). Int Dent J. 2003;53(4):237-42.

30- Young A, Jonski G, Rölla G. Inhibition of orally produced volatile sulfur compounds by zinc, chlorhexidine or cetylpyridinium chloride: effect of concentration. Eur J Oral Sci. 2003;111(5):400-4. 